\title{
Prolonged Oliguria with Survival in Acute Bilateral Cortical Necrosis
}

\author{
JOHN WALLS,* M.B., CH.B.; WAGNER J. SCHORR, *† M.D. ; DAVID N. S. KERR,* M.SC., F.R.C.P., F.R.C.P.ED.
}

Brit. med.F., 1968, 4, 220-222

\begin{abstract}
Cummary : Survival is uncommon in cases of acute $\checkmark$ bilateral cortical necrosis. Three cases admitted to the renal unit at Newcastle have regained useful renal function after oliguric phases of 38, 46, and 120 days.

Prolonged periods of intermittent dialysis are justified in patients in whom a firm diagnosis of acute cortical necrosis is made.
\end{abstract}

\section{Introduction}

Acute bilateral cortical necrosis of the kidney is a clinical entity which was first described by Juhel-Rénoy in 1886. Since then numerous clinical and pathological studies have suggested that it has an almost universally fatal outcome. However, in the past four decades there have been 14 individual reported survivors, two before the days of dialysis (Crook, 1927 ; Groen and Lindeboom, 1940 ; Gormsen et al., 1955; Alwall et al., 1957 ; Boucot et al., 1957 ; Lauler and Schreiner, 1958 ; Dérot et al., 1960 ; Milne, 1961 ; Effersøe et al., 1962 ; Oram et al., 1963 ; Vernon-Parry and Williams, 1963 ; Chervony et al., 1965 ; Rieselbach et al., 1967 ; Riff et al., 1967). We here report three further survivors who, after prolonged periods of oliguria (less than $400 \mathrm{ml} . / 24$ hours), recovered sufficient renal function to maintain life. Case 1 has previously been reported (Walls et al., 1966).

\section{Case 1}

A 13-year-old schoolboy was admitted to the Royal Victoria Infirmary unconscious after being involved in a motor accident on 3 December 1964 . No bony injury was found, and $200 \mathrm{ml}$. of dark blood-stained urine was obtained by catheterization. During the next 24 hours he complained of increasing abdominal pain, and at laparotomy a large retroperitoneal haematoma was found and drained. Postoperatively he was noted to be anuric. By the second post-trauma day his blood urea had risen to $322 \mathrm{mg} . / 100 \mathrm{ml}$. and he was transferred to the renal unit. The next day he had his first haemodialysis, which was repeated according to his rising blood urea.

On the 28th post-trauma day a retrograde pyelogram showed normal caliceal outlines and ureters. A percutaneous renal biopsy on the 51st day showed the changes of acute cortical necrosis (Fig. 1). Neither renal biopsy nor $x$-ray examination of the abdomen showed calcification in the kidneys. Because of the biopsy findings he was placed on regular outpatient haemodialysis therapy.

As time went by his pre-dialysis blood urea estimations gradually decreased (Fig. 2) and his urine output increased. In view of these facts and the difficulty in maintaining a satisfactory arteriovenous shunt it was decided to withhold his dialysis therapy on 16 September 1965-nine months after the onset of anuria. His blood urea gradually stabilized $(80-100 \mathrm{mg} . / 100 \mathrm{ml}$.) on a $40 \mathrm{~g}$. protein diet and free fluids with a urinary output of about $1,500 \mathrm{ml} . / 24$ hours. During this period he required Resonium-A (sodium polystyrene sulphonate) $15 \mathrm{~g}$. daily because of hyperkalaemia. He was normotensive. A creatinine clearance at one year post trauma was $8 \mathrm{ml} . / \mathrm{min}$. with a blood urea of $68 \mathrm{mg} . / 100 \mathrm{ml}$., though he had become hypertensive (B.P. 160/100) and was treated with methyldopa $250 \mathrm{mg}$. t.d.s.

Since then he has remained well and is able to carry out light work. When last seen in the outpatient department in February

- Renal Unit, Royal Victoria Infirmary, Newcastle upon Tyne 1. t Present address: 260 Oneida Street, Denver, Colorado, U.S.A
1968 the results of investigations were: blood urea $65 \mathrm{mg} . / 100 \mathrm{ml}$.; serum sodium $142 \mathrm{mEq} / 1$; ; serum potassium $5.5 \mathrm{mEq} / 1$. ; serum chloride $106 \mathrm{mEq} / \mathrm{l}$; ; bicarbonate $15 \mathrm{mEq} / 1$. ; serum creatinine $3.1 \mathrm{mg} . / 100 \mathrm{ml}$. ; creatinine clearance $24.5 \mathrm{ml} . / \mathrm{min}$. ; midstream specimen of urine sterile; haemoglobin $90 \%$; W.B.C. 9,000/ cu. mm. ; serum calcium $9.1 \mathrm{mg} . / 100 \mathrm{ml}$.; serum phosphate $4.3 \mathrm{mg} . / 100 \mathrm{ml}$; alkaline phosphatase 139 i.u. He is still mildly hypertensive. Repeat $x$-ray examination of the abdomen again failed to show renal calcification. $\mathrm{He}$ is on a free diet and unrestricted fluids and has achieved normal growth and development.

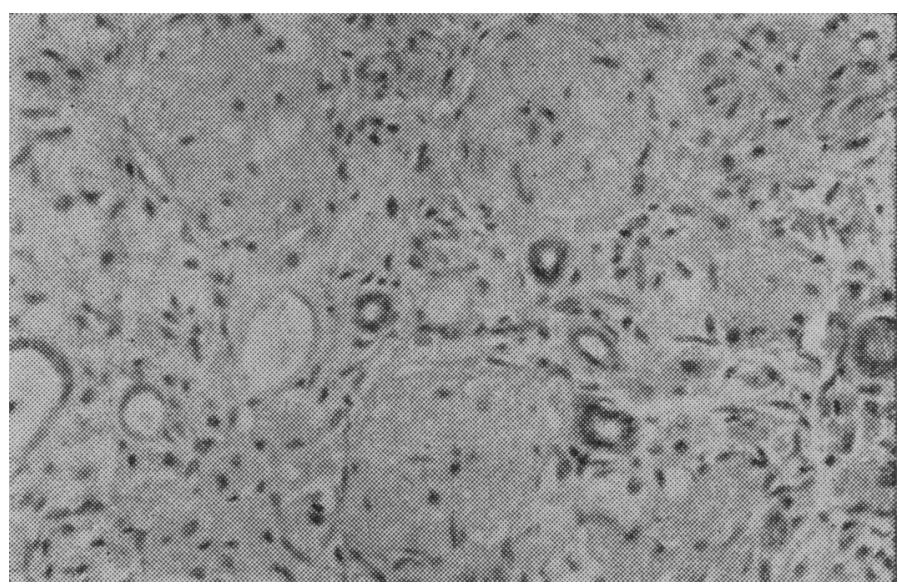

FIG. 1.-Case 1. Photomicrograph of renal biopsy showing acute cortical necrosis of the kidney. (H. and E. $\times 85$.)

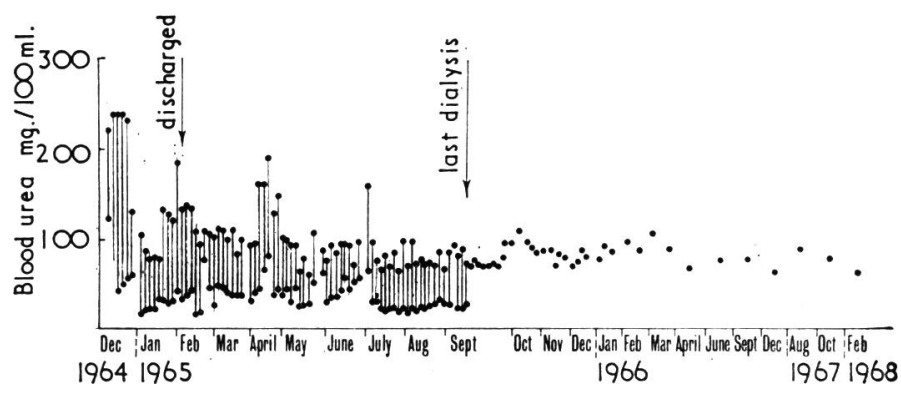

Fig. 2.-Case 1. Blood urea estimations showing gradual decrease while on regular outpatient haemodialysis therapy.

\section{Case 2}

This patient, a 53-year-old miner, had a long history of intermittent claudication in both legs. On 26 October 1967 he had a Dacron graft to the aortic bifurcation, below the renal arteries, in a four-hour operation, complicated by prolonged hypotension. His kidneys at the time of operation were noted to be normal and his preoperative blood urea was $38 \mathrm{mg} . / 100 \mathrm{ml}$. During the first postoperative 24 hours he passed $700 \mathrm{ml}$. of dark blood-stained urine but then became totally anuric for the next 20 days. $\mathrm{He}$ was transferred to the renal unit on the third postoperative day with a rising blood urea. Maintenance haemodialysis therapy was continued throughout his postoperative period, and on the 21 st day a percutaneous renal biopsy revealed outer cortical infarction but with a few juxtamedullary glomeruli well preserved. No calcium deposits were noted. 
It was thought that recovery of renal function was unlikely, and he was changed to regular outpatient haemodialysis therapy on the 26 th day, the urine volumes at that time being less than $100 \mathrm{ml}$./ 24 hours. By the 46th day he noted that his urine volumes had increased to $400 \mathrm{ml}$. on the day before dialysis. On the $52 \mathrm{nd}$ day the urine volume had increased to $1,340 \mathrm{ml} . / 24$ hours with a creatinine clearance of $3.8 \mathrm{ml} . / \mathrm{min}$., and haemodialysis was discontinued. During the period of regular haemodialysis therapy he has remained normotensive, Over the next four months he made a gradual clinical and biochemical improvement with a creatinine clearance of $6.8 \mathrm{ml} . / \mathrm{min}$. (see Table) and was on unrestricted fluids and a $60 \mathrm{~g}$. protein diet. Routine straight $x$-ray examination of his abdomen failed to show evidence of renal calcification. Decrease in Serum Creatinine and Increase in Creatinine Clearance
Over 108 days in Case 2.

\begin{tabular}{c|c|c}
\hline Days Postoperative & $\begin{array}{c}\text { Serum Creatinine } \\
(\mathrm{mg} / 100 \mathrm{ml} .)\end{array}$ & $\begin{array}{c}\text { Creatinine Clearance } \\
\text { (ml./min.) }\end{array}$ \\
\hline $0-46$ & $14 \cdot 2 *$ & - \\
52 & 16.9 & $2 \cdot 2$ \\
56 & $17 \cdot 4$ & 3.8 \\
72 & 11.4 & - \\
86 & 10.5 & $\overline{-}$ \\
100 & $9 \cdot 4$ & 6.8
\end{tabular}

- Mean pre-dialysis serum creatinine.

\section{Case 3}

A 22-year-old primigravida was admitted to the Princess Mary Maternity Hospital, Newcastle upon Tyne, following a concealed accidental haemorrhage when she was 36 weeks pregnant. After the haemorrhage she had an eclamptic fit and became anuric. On admission her blood urea was $78 \mathrm{mg} . / 100 \mathrm{ml}$., serum potassium $6.8 \mathrm{mEq} / \mathrm{l}$., and haemoglobin $59 \%$. Three days later she had an induced normal delivery of a stillborn infant, during which she lost a further $800 \mathrm{ml}$, of blood. She was transferred to the renal unit on the fifth day of anuria, when her blood urea was $192 \mathrm{mg} . /$ $100 \mathrm{ml}$., serum sodium $127 \mathrm{mEq} / 1$., serum potassium $4.2 \mathrm{mEq} / \mathrm{l}$., serum bicarbonate $16 \mathrm{mEq} / \mathrm{l}$., and haemoglobin $44 \%$.

She was treated by haemodialysis on four occasions, and by the tenth day had begun to pass small quantities of urine, $10-30 \mathrm{ml}$. On the 20th day a percutaneous renal biopsy revealed necrosis of glomeruli, tubules, interstitium, and vessels in the cortex. Occasionally the vessels contained recent thrombi. The medulla was spared. However, there were moderate amounts of calcified material in the interstitium and in some tubules. A diagnosis of acute bilateral cortical necrosis was made,

The urine volumes gradually increased until by the 40th day she was consistently passing over $1,000 \mathrm{ml} . / 24$ hours, with a creatinine clearance of $0.36 \mathrm{ml} . / \mathrm{min}$. The last dialysis was on the $43 \mathrm{rd}$ day, and by the 50th day her creatinine clearance had increased to $2 \mathrm{ml} . / \mathrm{min}$. She was able to maintain her blood urea below $200 \mathrm{mg} . / 100 \mathrm{ml}$. on a $20 \mathrm{~g}$. protein diet. During this period in hospital her progress was complicated by several epileptiform convuisions, which were eventually controlled by phenobarbitone and phenytoin sodium. Nephrotomography on the 43rd day showed bilateral cortical tram-line calcification (Fig. 3). She was eventually discharged on the 76th day, with a blood urea of $178 \mathrm{mg} . / 100 \mathrm{ml}$., to continue on a $40 \mathrm{~g}$. protein diet, $22 \mathrm{mEq}$ sodium diet, Resonium-A $15 \mathrm{~g}$. daily, and anticonvulsant therapy.

During the next three months she was admitted for blood transfusions on two occasions, and at one year her blood urea was $226 \mathrm{mg} . / 100 \mathrm{ml}$., serum creatinine $11.7 \mathrm{mg} . / 100 \mathrm{ml}$, and midstream specimen of urine sterile. Moderately severe hypertension (B.P. 175/125) found at this time was treated with methyldopa. She then ceased to attend outpatient clinics but was readmitted at 15 months with a two-month history of vomiting, diarrhoea, dyspnoea, and ankle-swelling. At this time she admitted to considerable dietary indiscretion. Her blood urea had risen to $426 \mathrm{mg}$./ $100 \mathrm{ml}$., her haemoglobin was $26 \%$, and her blood pressure was $165 / 100$, so she was started on regular outpatient haemodialysis therapy.

As suspected from her previous outpatient behaviour she was a difficult patient to manage, and became severely hypertensive (B.P. 240/140) and hyperkalaemic (serum potassium $7.2 \mathrm{mEq} / \mathrm{l}$.) on several occasions, despite drug therapy and warnings from the medical staff. She died suddenly on 16 April 1967 while walking in the street near her home. The most significant necropsy findings were: (1) A large heart (weight 500 g.) with considerable left ventricular enlargement but no infarction or fibrosis, The coronary arteries were also enlarged. (2) Both kidneys were shrunken (weight $55 \mathrm{~g}$. each). The capsule was adherent to the surface, and the cut surface showed complete absence of cortex in both kidneys. The most striking feature was the yellow stippled calcification of the outer rim of the kidney at the site of the defunct cortex. This dipped

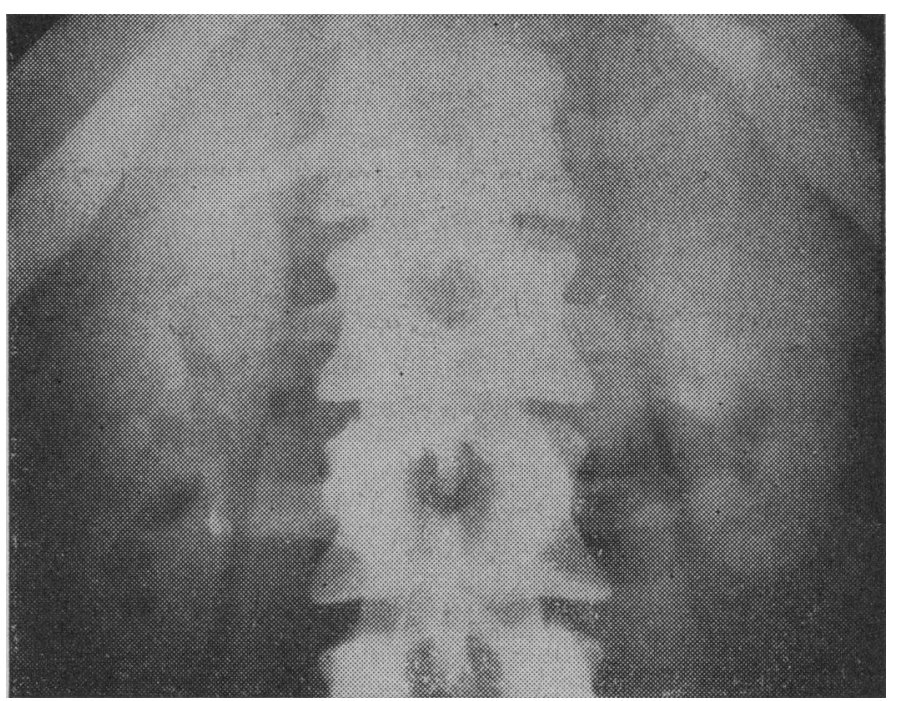

FIG. 3.-Case 3. Straight abdominal $x$-ray film showing renal calcification.

down beween medullary pyramids, and in many places there was a definite tram-line pattern of double lines. On histological examination there were very occasional normal-looking glomeruli. Marked hypertensive changes were noted in the large and small vessels and in the tufts of several glomeruli.

\section{Discussion}

Acute bilateral cortical necrosis is an uncommon cause of acute renal failure. Previous authors (Swann and Merrill, 1953 ; Lauler and Schreiner, 1958) have reported a $2 \%$ incidence of the lesion in cases of acute renal failure. From January 1961 to December 1967352 cases of acute renal failure were admitted to the renal unit of the Royal Victoria Infirmary. Of these, six had histological proof of acute bilateral cortical necrosis, which is in agreement with the previous estimates. Pregnancy, complicated by antepartum haemorrhage or eclampsia, is the commonest precipitating cause in adults (Sheehan and Moore, 1952). There are numerous other causes, including diabetes mellitus, trauma, surgery, snake-bites (Oram et al., 1963), and even spontaneous (Gormsen et al., 1955). In children the most common cause is dehydration due to diarrhoea and vomiting, followed by infections-that is, pneumonia, tonsillitis, peritonitis, and tuberculosis (Williams, 1963). In previously reported survivors, 11 out of 14 cases were in the obstetric group, though in the present series only one was an obstetric accident, the others being post-traumatic and postoperative.

The diagnosis of acute bilateral cortical necrosis is usually considered in cases of acute renal failure when the period of oliguria has exceeded 21 to 28 days. In the reported survivors the period of oliguria (less than $400 \mathrm{ml} . / 24$ hours) has varied from 7 to 60 days (Groen and Lindeboom, 1940 ; Alwall, 1957), with a mean duration of 28 days. Two further survivors were reported to have urinary outputs of $1,000 \mathrm{ml}$. or more per 24 hours by the 25 th and 32 nd days respectively (Boucot et al., 1957 ; Chervony et al., 1965). The surviving patients in this series were oliguric for 38,46 , and 120 days. Confirmation 
of the diagnosis can be made by either renal biopsy or finding renal cortical calcification on $x$-ray examination.

Renal biopsies in all reported cases, as with the present patients, have revealed necrosis of the glomeruli, tubules, interstitium, and vessels of the cortex. In some vessels there has been evidence of recent thrombosis. The renal medulla is spared and normal juxtamedullary glomeruli are occasionally found. Renal calcification is occasionally commented on. If needle biopsy shows findings compatible with the diagnosis of acute bilateral cortical necrosis one is still unable to predict the survival of the patient, owing to the patchy nature of the lesion and the sampling error of needle biopsies. This is illustrated by Case 1, which showed no surviving glomeruli, whereas in Case 2 not only was cortical necrosis present but juxtamedullary glomeruli with a normal appearance were shown.

Calcification of the renal cortex as a consequence of acute bilateral cortical necrosis has been reported in 5 of the 14 survivors (Groen and Lindeboom, 1940 ; Gormsen et al., 1955 ; Boucot et al., 1957 ; Oram et al., 1963 ; Vernon-Parry and Williams, 1963). As both the presence and the absence of calcification have been noted in the survivors it appears to have diagnostic rather than prognostic value. Calcification is found on biopsy as early as the fifth day and radiologically by 49 days (Moëll, 1957). In Case 3 calcification was present on renal biopsy by the 20 th day, the tram-line calcification, as described by Lloyd-Thomas et al. (1962), was noted by nephrotomography by the $43 \mathrm{rd}$ day.

Of the three non-surviving cases seen in this unit two showed some return of renal function after delivery. One patient, after 53 days of oliguria, achieved a urinary output of 1,000 $\mathrm{ml} . / 24$ hours and dialysis was stopped at this point. However, her renal function deteriorated and she died in renal failure on the 143rd day. The second patient, who also had untreated myxoedema ( ${ }^{131} \mathrm{I}$ uptake was $8 \%$ at 24 hours), was anuric for 35 days. Following this her urinary output gradually increased but never exceeded $500 \mathrm{ml} . / 24$ hours and dialysis was stopped on the 70 th day. Her blood urea rose to $470 \mathrm{mg}$. $/ 100 \mathrm{ml}$. by the 120th day, shortly after which she died. These two patients were admitted to the unit before the establishment of regular outpatient haemodialysis therapy. The third patient was a male with acute hepatic failure who died 48 hours after admission to hospital while still anuric.

Considering the length of the oliguric period followed by a return of some renal function in the present series, we feel that prolonged dialysis is justified in this group of patients. Once renal function is re-established continued improvement may occur, as seen in Cases 1 and 2. Other authors (Rieselbach et al., 1967) have noted the improvement in renal function over a long period of observations and suggested that improvement was due to functional adaptation of the nephron rather than to increase in the nephron population. The improvement in renal function, as seen in Case 1, is striking - that is, an increase in creatinine clearance from 8 to $24.5 \mathrm{ml}$./min. over 15 months. However, in Case 3 the renal function, having been reestablished, then deteriorated. The marked hypertension which occurred in this patient was possibly the cause of her deteriorating renal function. If prolonged dialysis therapy had been used in the treatment of the two postpartum non-survivors, with adequate management of the hypertension which occurred, ultimate recovery of sufficient renal function might have been achieved.

We wish to thank Dr. J. Hart-Mercer and the Department of Pathology for their help in preparing the photomicrograph in Case 1, also the Department of Radiology for the $x$-ray film in Case 3.

\section{REFERENCES}

Alwall, N. (1957). Arch. klin. Chir., 287, 579.

Boucot, N. G., Guild, W. R., and Merrill, J. P. (1957). New Engl. 3. Med., 257, 416.

Chervony, A. M., Biava, C. G., Schwartz, M. A., and West, M. (1965). Amer. F. Med., 39, 147.

Crook, A. (1927). Proc. roy. Soc. Med., 20, Part III, Section of Obstetrics and Gynaecology, p. 1249.

Dérot, M., Prunier, P., Roudier, R., and Mme. Prunier (1960). Bull. Soc. méd. Hôp. Paris, 76, 812 .

Effersøe, P., Raaschou, F., and Thomsen, A. C. (1962). Amer. F. Med., 33, 455 .

Gormsen, H., Iversen, P., and Raaschou, F. (1955). Amer. F. Med., 19, 209.

Groen, J., and Lindeboom, G. A. (1940). Ned. T. Geneesk., 84, 688.

Juhel-Rénoy, E. (1886). Arch. gén. Med., 17, 388.

Lauler, D. P., and Schreiner, G. E. (1958). Amer. F. Med., 24, 519.

Lloyd-Thomas, H. G., Balm, R. H., and Key, J. J. (1962). Brit. med. F., $1,909$.

Milne, M. D. (1961). In Ciba Symposium on Renal Biopsy, edited by G. E. W. Wolstenholme and M. P. Cameron, p. 189. London.

Moëll, H. (1957). Acta radiol. (Stockh.), 48, 355.

Oram, S., Ross, G., Pell, L., and Winteler, J. (1963). Brit. med. F., 1, 1647 .

Rieselbach, R. E., Klahr, S., and Bricker, N. S. (1967). Amer. F. Med., 42, 457 .

Riff, D. P., Wilson, D. M., Dunea, G., Schwartz, F. D., and Kark, R. M. (1967). Arch. intern. Med., 119, 518.

Sheehan, H. L., and Moore, H. C. (1952). Renal Cortical Necrosis and the Kidney of Concealed Accidental Haemorrhage. Oxford.

Swann, R. C., and Merrill, J. P. (1953). Medicine (Baltimore), 32, 215. Vernon-Parry, J., and Williams, R. T. (1963). Brit. med. F., 2, 903.

Walls, J., Redman, D., Elliott, R. W., and Kerr, D. N. S. (1966). Proceedings of European Dialysis and Transplant Association, 3, p. 349. Excerpta Medica International Congress Series, No. 131. Amsterdam.

Williams, T. F. (1963). In Diseases of the Kidney, edited by M. B. Strauss and L. G. Welt, p. 526. Boston. 